\title{
NOTES ON EURASIAN BARN SWALLOWS IN ALASKA, INCLUDING THE FIRST DOCUMENTATION OF SUCCESSFUL BREEDING IN NORTH AMERICA
}

\author{
BRYCE W. ROBINSON, 615 East Krall St., Boise, Idaho 83712; bryce@ornithologi.com \\ LUCAS H. DECICCO, Department of Ecology and Evolutionary Biology and \\ Biodiversity Institute, University of Kansas, Lawrence, Kansas 66045
}

\begin{abstract}
The Barn Swallow (Hirundo rustica) is a widespread and polytypic species comprising six to eight subspecies (see Vaurie 1959, Peters 1960, Cramp 1988, Brown and Brown 1999, Dickinson and Dekker 2001, Turner 2004, Dor et al. 2010, Dickinson and Christidis 2014). The New World subspecies (H. r. erythrogaster) breeds over parts of South America (Grande et al. 2015) and most of North America, north and west to Alaska (Brown and Brown 1999). In Alaska it is a fairly common or uncommon breeder, respectively, in southeastern and south-central Alaska, and a casual visitant elsewhere in the state (Gabrielson and Lincoln 1959, Kessel and Gibson 1978, Gibson and Kessel 1997, Gibson and Withrow 2015). Historically the species bred more widely in Alaska; however, sometime in the past century its range contracted substantially (Kessel and Gibson 1994, Gibson and Withrow 2015). Additionally, two Eurasian subspecies occur as visitants in Alaska. Both differ from erythrogaster in having whitish rather than rufous underparts (Phillips 1986): H. r. rustica, which breeds across Europe, the Middle East, and western Asia, and H. r. gutturalis, which breeds south and east of rustica from Amurland and Ussuriland in the Russian Far East south to northern China, Korea, and Japan (Turner 2004). There are no previous confirmed records of the Eurasian taxa breeding in North America. Here we review and update the status of the two Eurasian taxa in Alaska and document the successful breeding of a pair of H. r. gutturalis in western Alaska.
\end{abstract}

\section{OBSERVATION AND IDENTIFICATION OF EURASIAN BARN SWALLOWS AT NOME}

On 28 July 2016 we observed an adult white-bellied Barn Swallow in the Nome Department of Transportation's utility yard, approximately $4 \mathrm{~km}$ northwest of Nome on the Seward Peninsula, western Alaska. On 5 August at the same location, Robinson heard calls of begging young that led him to two adult Barn Swallows (Figure 1) attending four fledglings perched on light fixtures attached to the side of a building (Figure 2). He observed and photographed the pair provisioning the fledglings multiple times over a 10-minute period, during which the fledglings also made brief foraging flights to attempt to capture insects themselves. Unfortunately, because of his impending departing flight out of Nome, further study was not possible.

We identified the two adult Barn Swallows nesting in Nome as H. r. gutturalis after comparing our photographs of these birds to published descriptions of plumage variation among the subspecies (e.g., Phillips 1986) and to photographs of specimens of H. r. erythrogaster, rustica, and gutturalis housed at the American Museum of Natural History (AMNH), New York, and the University of Alaska Museum (UAM), Fairbanks. On the basis of photographs of specimens at AMNH, Robinson illustrated the differences among these taxa (Figure 3), providing a comparison for the birds at Nome. The Nome breeders best matched the illustrated distillations of gutturalis (Figure $3 \mathrm{C}$ and $\mathrm{D}$ ) and differed from nominate rustica (Figure $\mathrm{BA}$ and $\mathrm{B}$ ) in having a less complete breast band and proportionally shorter tail streamers. They differed 


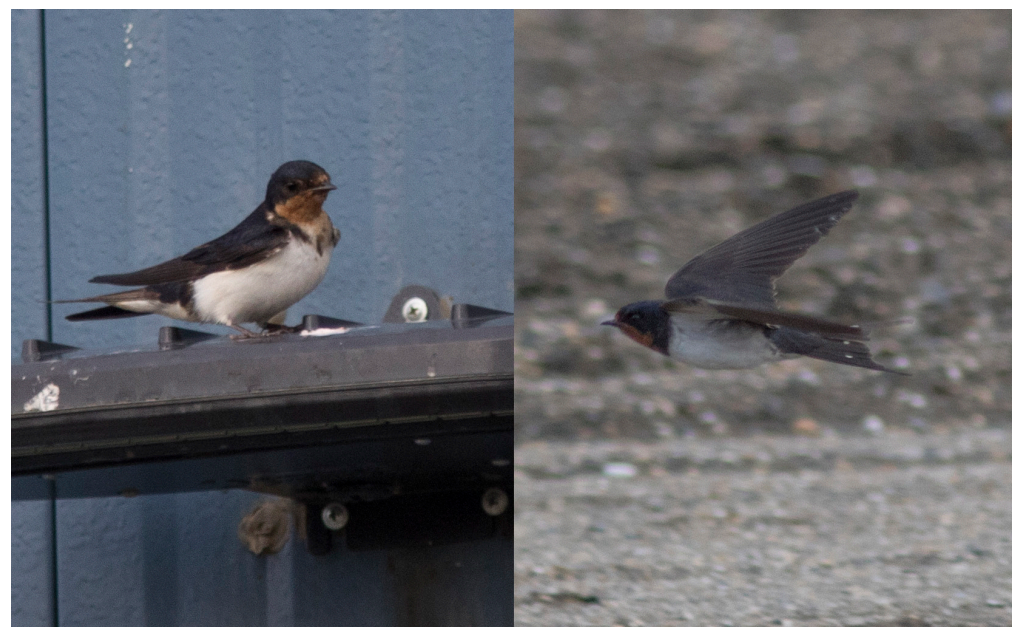

Figure 1. Two adult Eurasian Barn Swallows (H. r. gutturalis) that we observed provisioning four fledglings near Nome, Alaska, on 5 August 2016. Plumage features that support our identification of the birds as subspecies gutturalis include short outer tail feathers (relative to those of nominate rustica), whitish underparts, and broken breast band (compare Figure 3).

Photos by Bryce W. Robinson/USFWS

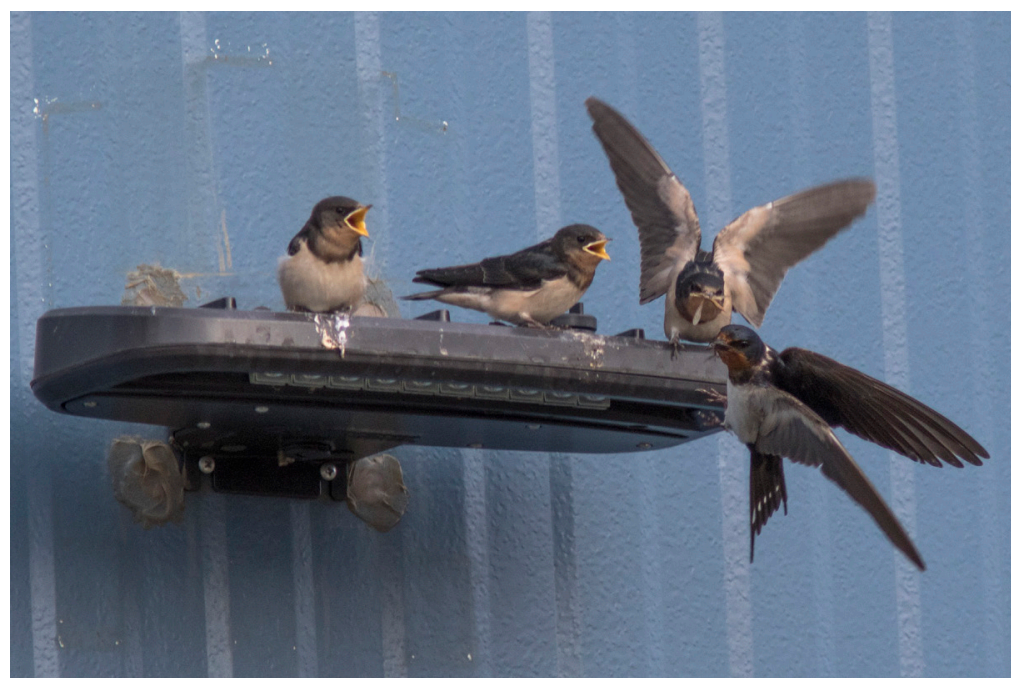

Figure 2. Three of four fledgling Eurasian Barn Swallows (H. r. gutturalis) being provisioned by an adult on 5 August 2016 near Nome, Alaska. Over 10 minutes, we observed two adults repeatedly attending the fledglings, which also made flights to attempt to capture insects themselves.

Photo by Bryce W. Robinson/USFWS 
H. r. rustica

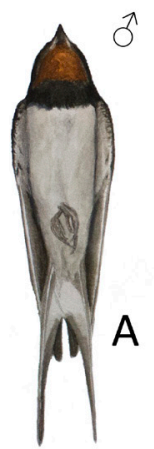

H. r. gutturalis

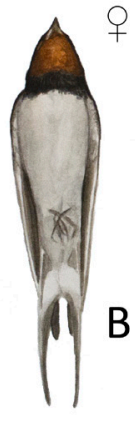

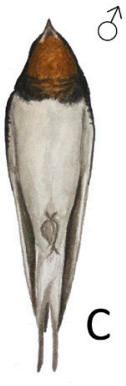

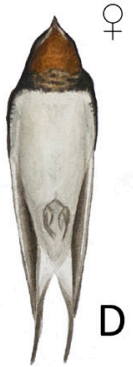

H. r. erythrogaster

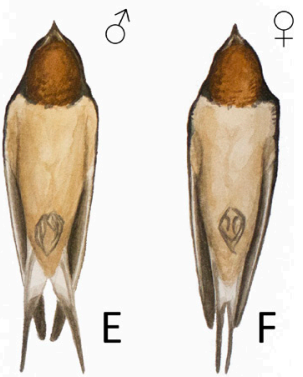

Figure 3. Three subspecies of the Barn Swallow: H. r. rustica (A, male; B, female), $H$. r. gutturalis (C, male; $\mathrm{D}$, female), and H. r. erythrogaster (E, male; $\mathrm{F}$, female). The plumage of the birds that nested near Nome was most similar to $C$ and $D$ with whitish underparts, relatively short outer tail feathers, and a broken incomplete breast band. Illustrations are composites based on photos of 18 specimens (six per taxon) provided by the American Museum of Natural History.

Illustrations by Bryce W. Robinson

also from erythrogaster (Figure 3E and F) in their whitish underparts and more extensive breast band.

\section{SPECIMENS OF THE EURASIAN SUBSPECIES OF THE BARN SWAL- LOW IN ALASKA AND THEIR IDENTIFICATION}

Nominate rustica and H. r. gutturalis have been documented in Alaska by a combined total of seven specimens (Table 1). Gibson and Withrow (2015) regarded both taxa as casual visitants in Alaska with rustica substantiated by two specimens, FMNH (Field Museum of Natural History, Chicago) 174044 and UAM 3781, both from Utqiagivik (Barrow), and gutturalis by three, UAM 2905, UAM 2577, and UAM 2808, from St. Lawrence I., Old Chevak, and Agattu I., respectively. Two additional specimens exist: CHAS (Chicago Academy of Sciences) 5254, identified (on the label) by H. Friedmann as gutturalis, and USNM (U. S. National Museum, Washington, D.C.) 337966, identified (on the label) by A. R. Phillips (in 1986) as nominate rustica, although Friedmann (in 1939) had identified it as gutturalis. Photos show that CHAS 5254 has a thick and complete dark breast band, a characteristic of rustica, not gutturalis. As for USNM 337966, photos show that its venter is not whitish, casting doubt on its identification as either rustica or gutturalis. Therefore, for the time being, this specimen may better be left unidentified to subspecies. The subspecific identity of the Agattu I. specimen (UAM 2808) has likewise been in flux (cf. Byrd et al. 1978, Phillips 1986, Gibson and Byrd 2007), and annotations on the labels make clear the tentative nature of several others.

Variation in the phenotype of Barn Swallows across Asia is complex, and "populations in Eurasia intergrade" (Turner 2004:665). We are unaware of any treatment outlining methods for diagnosing (sensu Patten and Unitt 2002) particular subspecies, thus the difficulties in determining the origins of some such Barn Swallows recorded in Alaska. In one example of the Barn Swallow's uncertain taxonomy in east Asia, Vaurie (1954:11) stated, "In H. rustica the status of the populations found 
Table 1 Records of Eurasian Barn Swallows in Alaska with Documentation Sufficient for a Tentative Identification to Subspecies

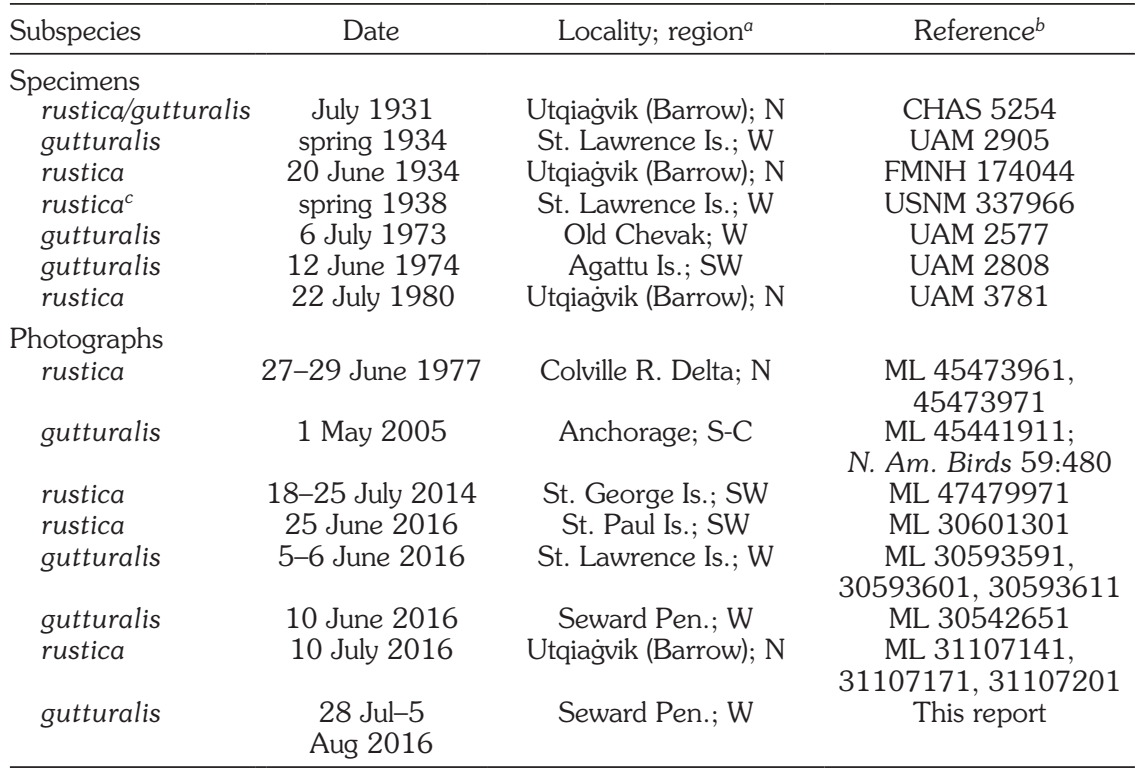

${ }^{a}$ As outlined by Gibson and Withrow (2015): N, northern; S-C, south-central; SW, southwestern; W, western.

bSpecimens are deposited at the Chicago Academy of Sciences (CHAS); Field Museum of Natural History, Chicago (FMNH); Univerity of Alaska Museum, Fairbanks (UAM); and U.S. National Museum of Natural History, Smithsonian Institition, Washington, D.C. (USNM). Photographs are archived at the Macaulay Library, Cornell University, Ithaca, New York (ML).

'This specimen's venter is not entirely white, having some rufous in the wing pits and more laterally on the flanks, suggesting that its identification as rustica by A. R. Phillips (or as gutturalis by H. Friedmann), is uncertain.

in Siberia from about the Yenisei eastward to the coasts of the Sea of Okhotsk and Kamchatka south to Manchuria and northern Hopeh is not clear ... [these populations are] very variable." The orange-bellied populations breeding in the Kamchatka Peninsula and around the Sea of Okhotsk have been considered a subspecies for which the oldest name is saturata. Dementiev and Gladkov (1968) designated most of these as erythrogaster but suggested alternatively that they may instead represent intergradation between gutturalis and the orange-bellied subspecies tytleri (breeds in central Siberia and northern Mongolia north and northwest of gutturalis). This view was also expressed by Smirenskiy and Mishchenko (1981; see also Dickinson and Dekker 2001). Also problematic is how the orange-bellied tytleri or saturata (as listed by Dickinson and Christidis 2014) may be distinguished from erythrogaster (e.g., see Ridgway 1904), although they are considered by some sources to have a more extensive breast band (Turner and Rose 1989, Brown and Brown 1999). Their described ranges suggest their likelihood of reaching Alaska is at least as great as that of gutturalis and much more likely than that of nominate rustica (breeds no closer than the basin of the Yenisei River in central Siberia). Stejneger (1885) reported tytleri from the Commander Islands. The identification of extralimital birds is clearly 
fraught with uncertainty (e.g., Clancy 1970), background for the following discussion of photographic and specimen evidence.

Most reports of Eurasian Barn Swallows in Alaska are based on observations of "white-bellied" birds. We reviewed eight records supported by photos of sufficient quality (now archived at the Macaulay Library) of Eurasian Barn Swallows in Alaska from 1977 to 2016 (Table 1). There are additional photo-documented records that we did not consider because of the photos' poor quality or because the birds' plumage was ambiguous. Of these eight records, we suggest that four from northern Alaska and from the Pribilof Islands in southwestern Alaska represent rustica and four from western, southwestern, and south-central Alaska represent gutturalis (Table 1). On the basis of the previously reviewed specimens and these photographic records, we suggest that subspecies rustica be considered casual in northern, western, and southwestern Alaska and that subspecies gutturalis be considered casual in northern, western (where it has now bred), southwestern, and south-central Alaska.

\section{STATUS OF THE BARN SWALLOW ON THE SEWARD PENINSULA}

With "only half a dozen" reports, Kessel (1989:236) regarded the Barn Swallow as a "very rare spring migrant and early summer visitant" on the Seward Peninsula. In this area, the North American subspecies erythrogaster appears to be more regular than either Eurasian taxon. In addition to the nesting in 2016, we were able to find two records of probable Eurasian birds on the Seward Peninsula: of one "white-bellied" bird on 13 June 2000 at Teller (North American Birds 54:413, 2000; no photo) and one on 10 June 2016 at Salmon Lake $50 \mathrm{~km}$ inland from Nome (C. Turner and R. Cimino, in litt., 2016; appeared to be gutturalis from a single photo). We are aware of just one previous recent nesting record of the species for the Seward Peninsula: a pair of rusty-bellied birds, presumably erythrogaster, at Solomon, $50 \mathrm{~km}$ to the east of Nome along the Nome-Council road in summer 2008 (North American Birds $62: 604,2008)$. Late in the $19^{\text {th }}$ century Barn Swallows reported as erythrogaster were regularly found breeding near the Seward Peninsula at Kotzebue Sound (Grinnell 1900; MVZ [Museum of Vertebrate Zoology, University of California, Berkeley] egg 386), St. Michael (Nelson 1883; MVZ egg 692), and Nulato (Nelson 1887). The species' status on the Seward Peninsula at that time is likely to have been similar, e.g., Adams (1878) reported nesting at Port Clarence in 1851 (see also McGregor 1902).

\section{ECOLOGY OF BARN SWALLOW NESTING IN THE TUNDRA}

Barn Swallows are known for nesting on artificial structures, in some areas exclusively (e.g., Isleib and Kessel 1973, Heinl and Piston 2009). This predilection has allowed the species to breed elsewhere in peripheral, coastal locations in northern and western Alaska at Cape Sabine (Childs and Maher 1960), Icy Cape (Lehnhausen and Quinlan 1981), Utqiagivik (Bailey 1948), and the outer Yukon-Kuskokwim delta (Walkinshaw and Stophlet 1949; see also Harris 1967). The subspecific affinities of these birds have not always been addressed, but a specimen collected near the Cape Sabine nest is listed as erythrogaster (MVZ 140241) and Bailey (1948) discussed the second-hand report at Utqiagivik by Charles Brower under erythrogaster.

The breeding of Barn Swallows near Nome in 2016, the first confirmed in North America by any subspecies besides $H$. $r$. erythrogaster, is notable given the status of Eurasian Barn Swallows in Alaska. It is also of interest that this event took place in the same year as the first recorded Alaska breeding of the Eastern Phoebe (Sayornis phoebe), $18.5 \mathrm{~km}$ from the location of the Barn Swallow nest (Robinson et al. 2017). For species largely dependent on artificial structures for nesting, such as the Eastern Phoebe and the Barn Swallow, further such development may facilitate additional 
extralimital breeding. This may lead to changes in the species' distribution (Okes et al. 2008, Livezy 2009), especially if compounded by the effects of climate change, which have been correlated with changes in birds' distributions in Europe (Massimino et al. 2015) and elsewhere. To expand our understanding of the human influence on the natural world, it is important to document extralimital breeding through publications such as this and other forms of contributions such as data entered at www.eBird. org. Further diligence in documenting extralimital breeding by the Barn Swallow in places such as Alaska may provide a foundation for understanding shifts in breeding distributions and provide insights into historical changes.

\section{ACKNOWLEDGMENTS}

We thank Pavel Tomkovich, Georgy Semenov, Elizabeth Scordato, and Rebecca Safran for their comments on the subspecific identification of the Nome birds. We thank Paul Sweet at the American Museum of Natural History for providing photographs of the specimens used for identification and the creation of Figure 3. Chris Milensky (U. S. National Museum, Smithsonian Institution), Mary Hennen (Field Museum of Natural History), Mark B. Robbins (University of Kansas), and Dawn Roberts (Chicago Academy of Sciences) provided photographs of Alaska specimens at their institutions. We thank Theodore G. Tobish Jr. and Scott Schuette for help with details of some Alaska Barn Swallow records, and the following photographers on whose material part of this note is based: Christian Hagenlocher, Jim W. Helmericks, Theodore G. Tobish Jr., Wyatt Egelhoff, Stephan Lorenz, Aaron J. Lang, and Craig Turner. Reviews of the manuscript by Daniel R. Ruthrauff, Daniel D. Gibson, Steven C. Heinl, and Jack J. Withrow are greatly appreciated. Finally, we thank James A. Johnson and the U. S. Fish and Wildlife Service for providing the opportunity for our time in Nome, without which these observations would not have been made.

\section{LITERATURE CITED}

Adams, E. 1878. Notes on the Birds of Michalaski, Norton Sound. Ibis 20:420-442; doi 10.1111/j.1474-919X.1878.tb07055.x.

Bailey, A. M. 1948. Birds of Arctic Alaska. Colorado Mus. Nat. Hist. Pop. Ser. 8:1-137.

Brown, C. R., and Brown, M. B. 1999. Barn Swallow (Hirundo rustica), in The Birds of North America (A. Poole and F. Gill, eds.), Birds N. Am., Philadelphia; doi $10.2173 /$ bna. 452 .

Byrd, G. V., Trapp, J. L., and Gibson, D. D. 1978. New information on Asiatic birds in the Aleutian Islands, Alaska. Condor 80:309-315; doi 10.2307/1368041.

Childs, H. E. Jr., and Maher, W. J. 1960. Nesting attempt by a pair of Barn Swallows in northern Alaska. Condor 62:141-142.

Clancy, P. A. 1970. Miscellaneous taxonomic notes on African birds, XXVIII. Durban Mus. Nov. 8:325-351.

Cramp, S. (eds.). 1988. Birds of the Western Palearctic, vol. V. Oxford Univ. Press, Oxford, England.

Dementiev, G. P., and Gladkov, N. A. 1968. Birds of the Soviet Union. Israel Program for Scientific Translations, Jerusalem.

Dickinson, E. C., and Christidis, L. (eds.). 2014. The Howard and Moore Complete Checklist of the Birds of the World, $4^{\text {th }}$ ed., vol. 2: passerines. Aves Press, Eastbourne, England.

Dickinson, E. C., and Dekker, R. W. R. J. 2001. Systematic notes on Asian birds. 13. A preliminary review of the Hirundinidae. Zool. Verh. Leiden 335:127-144.

Dor, R., Safran, R. J., Sheldon, F. H., Winkler, D. W., and Lovette, I. J. 2010. Phy- 
logeny of the genus Hirundo and the Barn Swallow subspecies complex. Mol. Phylogen. Evol. 56:409-418; doi 10.1016/j.ympev.2010.02.008.

Gabrielson, I. N., and Lincoln, F. C. 1959. The Birds of Alaska. Stackpole, Harrisburg, PA.

Gibson, D. D., and Byrd, G. V. 2007. Birds of the Aleutian Islands, Alaska. Union Series Ornithol. 1, Nuttall Ornithol. Club and Am. Ornithol. Union.

Gibson, D. D., and Kessel, B. 1997. Inventory of the species and subspecies of Alaska birds. W. Birds 28:45-95.

Gibson, D. D., and Withrow, J. J. 2015. Inventory of the species and subspecies of Alaska birds, second edition. W. Birds 46:94-185.

Grande, J. M., Santillán, M. A., Orozco, P. M., Liébana, M. S., Reyes, M. M., Galmas, M. A., and Ceregheti, J. 2015. Barn Swallows keep expanding their breeding range in South America. Emu 115:256-260; doi 10.1071/MU14097.

Grinnell, J. 1900. Birds of the Kotzebue Sound region, Alaska. Pac. Coast Avifauna 1.

Harris, S. W. 1967. Summer birds of the lower Kashunuk River, Yukon-Kuskokwim Delta, Alaska. Murrelet 47:57-65; doi 10.2307/3533669.

Heinl, S. C., and Piston, A. W. 2009. Birds of the Ketchikan area, southeast Alaska. W. Birds 40:54-144.

Isleib, M. E., and Kessel, B. 1973. Birds of the North Gulf Coast-Prince William Sound region, Alaska. Biol. Papers Univ. Alaska 14 (reprinted with addendum 1989).

Kessel, B. 1989. Birds of the Seward Peninsula, Alaska: Their Biogeography, Seasonality, and Natural History. Univ. Alaska Press, Fairbanks.

Kessel, B., and Gibson, D. D. 1978. Status and distribution of Alaska birds. Studies Avian Biol. 1.

Kessel, B., and Gibson, D. D. 1994. A century of avifaunal change in Alaska, in A century of avifaunal change in western North America (J. R. Jehl Jr. and N. K. Johnson, eds.), pp. 4-13. Studies Avian Biol. 15.

Lehnhausen, W. A., and Quinlan, S. E. 1981. Bird migration and habitat use at Icy Cape, Alaska. Office of Special Studies, U.S. Fish and Wildl. Serv., 1011 E. Tudor Rd. \#200, Anchorage, AK 99503.

Livezy, K. B. 2009. Range expansion of Barred Owls, part I: Chronology and distribution. Am. Midland Nat. 161:49-56; doi 10.1674/0003-0031-161.1.49.

Massimino, D., Johnston, A., and Pearce-Higgins, J. W. 2015. The geographical range of British birds expands during 15 years of warming. Bird Study 62:523534; doi 10.1080/00063657.2015.1089835.

McGregor, R. C. 1902. A list of birds collected in Norton Sound, Alaska. Condor 4:135-144; doi 10.2307/1360889.

Nelson, E. W. 1883. Birds of the Bering Sea and the Arctic Ocean, in Cruise of the Revenue-Steamer Corwin in Alaska and the N. W. Arctic Ocean in 1881, pp. 57-118. Govt. Printing Office, Washington, DC.

Nelson, E. W. 1887. Birds of Alaska, in Report upon Natural History Collections Made in Alaska between the Years 1877 and 1881 (H. W. Henshaw, ed.), pp. 35-322. U.S. Army Signal Service Arctic Series 3. Govt. Printing Office, Washington, DC.

Okes, N. C., Hockey, P. A. R., and Cumming, G. S. 2008. Habitat use and life history as predictors of bird responses to habitat change. Conserv. Biol. 22:151-162; doi 10.1111/j.1523-1739.2007.00862.x.

Patten, M. A., and Unitt, P. 2002. Diagnosability versus mean differences of Sage Sparrow subspecies. Auk 119:26-35; doi 10.2307/4090009.

Peters, J. L. 1960. Checklist of Birds of the World, vol. IX. Mus. Comp. Zool, Cambridge, MA.

Phillips, A. R. 1986. The Known Birds of North and Middle America, part I. A. R. Phillips, Denver.

Ridgway, R. 1904. The birds of North and Middle America. Bull. U. S. Natl. Mus. 50, part III. 
Robinson, B. W., DeCicco, L. H., Bowman, A., Hauser, S. and Wright, J. M. 2017. First record of the Eastern Phoebe (Sayornis phoebe) breeding in Alaska: Extralimital by $2000 \mathrm{~km}$. W. Birds 48:145-147.

Smirenskiy, S. M., and Mishchenko, A. L. 1981. Taxonomical status and history of formation of the range of Hirundo rustica in the Amur territory. Zool. Zh. 60:1533-1541.

Stejneger, L. 1885. Results of ornithological explorations in the Commander Islands and Kamtschatka. Bull. U.S. Nat. Mus. 29:1-382; doi 10.5479/ si.03629236.29.1.

Turner, A. 2004. Family Hirundinidae (swallows and martins), in Handbook of the Birds of the World (J. Del Hoyo, A. Elliott, and D. Christie, eds.), vol. 9, pp. 602-685. Lynx Edicions, Barcelona, Spain.

Turner, A. K., and Rose, C. 1989. Swallows and Martins: An Identification Guide and Handbook. Houghton Mifflin, Boston.

Vaurie, C. 1954. Systematic notes on palearctic birds, no. 12. Muscicapinae, Hirundinidae, and Sturnidae. Am. Mus. Nov. 1694:1-18.

Vaurie, C. 1959. The Birds of the Palearctic Fauna: Passeriformes. H. F. and G. Witherby, London.

Walkinshaw, L. H., and Stophlet, J. J. 1949. Bird observations at Johnson River, Alaska. Condor 51:29-34; doi 10.2307/1364839.

Accepted 20 July 2017 